\title{
Foreign Direct Investment and Sustainable Development in Nigerian Aviation
}

\author{
Adejoke 0. Adediran \\ Nigerian Institute of Advanced Legal Studies, Abuja \\ jokediran77@yahoo.com
}

\begin{abstract}
The aviation industry is capital intensive and government budgetary allocation to the industry in Nigeria has proven insufficient, making private investment an imperative for the development of more effective air transport services and infrastructure. The industry is open to foreign investments, which have indeed accounted for significant development in Nigeria. Challenges arise, however, when the regulation of Foreign Direct Investment (FDI) attempts to reconcile sustainable development with long-term benefits for the host economy. This paper examines the regulation of FDI in the aviation industry of Nigeria and argues that there is need for the law to emphasize that the corporate social responsibilities of foreign companies in the industry should facilitate infrastructural development especially.
\end{abstract}

\section{Introduction}

Foreign direct investment (FDI) has been seen as a driver of development and a means to achieve sustainable development (Kardos 2014). Many developing countries are consequently embracing FDI within their jurisdictions (Kaur 2013) and Nigeria is such a case (Taiwo et al. 2017). But the inflow of FDI can also have negative effects on economic sustainability in host countries when domestic producers are "squeezed from the market" (Susic et al. 2017). Accordingly, the regulation of FDI in developing countries to emphasise its long-term benefits to the host economy are gaining ground as the international community stresses the need to mobilise investment that contributes to the sustainable development of host countries (United Nations Conference for Trade and Development [UNCTAD] 2015, p.6). Developing countries are reviewing their legal and policy regimes to reflect inclusive FDI which promotes sustainable development.

The aviation industry in Nigeria is an important aspect of the national economy as it creates direct employment opportunities and is a catalyst for 
wealth creation. The aviation industry significantly facilitates the flow of FDI into Nigeria as availability of an air transportation system is a crucial determinant to the flow of FDI (Stephens et al. 2014). The spill-over effect from the aviation industry is also a basis for foreign investment. Given the prevalence of FDI in the aviation industry, it is important that legal and policy regulation in the industry is geared towards sustainable development more generally. This paper examines the application of FDI to the aviation industry and the concept of sustainable development within it. It describes laws and policies governing FDI generally in Nigeria, covering international investment treaties and policies, and aviation specific laws and regulations providing for foreign investments. It concludes that significant reform is needed to legislation and practice.

\section{Foreign Direct Investment}

FDI is defined as an investment made to acquire a lasting management interest in a business enterprise operating in a country which is not that of the investor (OECD 2008). FDI transfers "tangible or intangible assets from one country to another for the purpose of their use in that country to generate wealth under the total or partial control of the owner of the assets" (Sornarajah 2010, p. 8). FDI is distinguished from Foreign Portfolio Investment (FPI) which is normally represented by a movement of money for the purpose of buying shares in a company formed or functioning in another country. So while FDI is signified by a wholly foreign company operating in Nigeria, FPI is characterised by a foreign company or foreign investor having investment interests in a Nigerian business.

FDI has since been protected under Customary International Law based on the principle of treatment of aliens whereby it is expected that physical assets of foreigners should be protected by the host country. FPI, on the other hand, is only protected in international law through investment treaties (Sornarajah 2010, p. 9). Investment treaties cover any investment of the nationals of one country in another, and state parties to an investment treaty agree to extend certain protection to the investment of nationals of the other country situated in their own. The analysis below focuses on the regulation of FDI to ensure that it fosters sustainable development.

\section{Sustainable Development}

Sustainable development has been defined as the "development that meets the needs of the present without compromising the ability of future generations to meet their own needs" (Strange \& Bayley, 2008). Agenda 21 of the United Nations Conference on Environment and Development 
(UNCED) 1992, also known as the Rio Earth Summit of 1992, identified the three pillars of sustainability to be economic, social and environmental (UNCED, 1992). States were to develop national strategies aimed at ensuring "socially responsible economic development while protecting the resource base and the environment for the benefit of future generations" (UNCED 1992, para. 8.7). The United Nations Conference on Sustainable Development (UNCSD) of 2012 further called on states to commit to sustainable development and to ensure the promotion of an economically, socially and environmentally sustainable future for present and future generations (UNCSD 2012). This prompted the adoption of a Resolution by the United Nations General Assembly which recognised the necessity of integrating economic, social and environmental aspects of sustainable development at all levels so as to achieve sustainable development in all facets of life (66/288, 27 July 2012, Annex I para. 3).

The economic dimension of sustainable development has been described as the promotion of economic growth by an "increase in the endogenous capacities of domestic firms and workers to learn, innovate and produce for domestic and or global markets" (Gallagher \& Zarsky 2007, p.5). The social dimension of sustainable development is centred around eradication of poverty by strengthening employment and income-generating programs, while the environmental pillar of sustainable development calls for the conservation and protection of resources. To promote sustainable development, host countries thus need to develop domestic industries and capacity, ensure the local transfer of knowledge and technology, and also mitigate the environmental impacts of industrial growth (Gallagher \& Zarsky 2007, p.5).

The need to ensure that foreign investment contributes to sustainable development has led to the emergence of a new breed of investment policies that put inclusive growth and sustainable development at the centre of efforts to attract and benefit from investment (UNCTAD 2015, p.6; Giffen 2015). The Nigerian experience of using BITs to strengthen sustainable development is however mixed (for an extended consideration of the utility of BITs, see the article by Dagbanja in this issue). On the one hand, the Investment treaty between Nigeria and Morocco of 2016 acknowledges that the environmental laws and policies of each country, and the multilateral environmental agreements to which both are parties, play an important role in protecting the environment; each party undertakes to observe social responsibilities owed to the other party; the host state can take regulatory measures to ensure that development in its territory is consistent with the goals and principles of sustainable development and with other legitimate 
social and economic policy objectives; and Corporate Social Responsibility is specifically endorsed (Investment Promotion and Protection Agreement ... Morocco ....Nigeria 2016). On the other, it is noteworthy the BIT between Nigeria and China of 2001 does not contain any sustainable development provisions, even though Chinese investments have been notable in the industry, as seen in the involvement of a Chinese firm in the construction of the Abuja airport terminal building."

The assessment of Nigeria's record below uses the United Nations 2030 Agenda for Sustainable Development as a guide. Of the seventeen Sustainable Development Goals (SDGs) at the core of the Agenda, fifteen are connected to aviation (International Civil Aviation Organization [ICAO] 2016). We examine the SDGs covering poverty, education, decent work and economic growth, industry innovation and infrastructure, and climate actions.

\section{FDI and the Nigerian aviation industry}

The aviation industry is capital intensive (Capobianco and Fernandes 2004) considering the resources required in the airline business and for aviation infrastructure. A spillover of operational costs on consumers and passengers usually results in the form of airport charges and taxes as reliance is placed on revenue generated from airport-related activities (Schlumberger \& Vijayakuma 2015, p. 494). Thus in Nigeria, air passengers pay taxes to airlines and they also pay charges to the Federal Airports Authority of Nigeria (FAAN). It has been noted that passengers on domestic flights even pay more taxes and charges than the ticket fare itself (Daily Trust, 2017). The charges paid to the airport authority such as the Passenger Service Charge and Ticket Sale Charge are usually meant for the improvement of services in the industry. Passengers in some cases may have to bear the obligations that consumer protection places on airlines in the form of increased air fares (Adediran 2018, p. 92), especially where there is an absence of adequate liability insurance.

While government allocation is a source of revenue in the Nigerian aviation industry, it is not reliable. Budgetary allocation are hardly sufficient and it is even often less than that allocated for other forms of transportation. In 2017, for instance, a sum of N20billion went to the aviation sector out of the N262 billion budget estimated for transportation (Appropriation Act 2017 Parts $\mathrm{C}$ and D). It was noted that the amount was too small considering the "myriad of work to be done" in the aviation sector (Agabi 2017). The paucity of revenue from the government to the aviation sector has thus required the industry to seek private investments to thrive, and the Federal 
Government has declared its commitment to attracting increased trade and inflow of FDI into Nigerian aviation industry (Vanguard 2018). The National Civil Aviation Policy (NCAP) of 2013, which is current, also advocates for the enhancement of the aviation industry in Nigeria through private sector participation and foreign direct investment (NCAP 2013).

Here we note some of the initiatives of the Nigerian government that are intended as catalysts for foreign investments in the aviation industry. Nigeria became a member of the Single African Air Transport Market (SAATM), launched in January 2018 by the African Union (AU) (Assembly/AU/Commitment [XXIV] 2015), that aims to liberalise civil aviation in Africa through a unified air transport market. SAATM may enhance cross-border investment in the industry, as it has been observed that FDI is now carried out not only by multinational entities but also by small firms in developing countries that are investing in a country other than their home country (Qiang et al., 2015). Private investment in aviation infrastructure is on the increase globally as governments find it difficult to meet the operational requirements flowing from the growing demand in air travel (Schlumberger \& Vijayakuma 2015, p. 493) and collaborations with the private sector have seemingly produced positive results. An example was the rehabilitation of Terminal II of the Murtala Muhammed Airport in Lagos by Bi-Courtney Consortium under the Build, Operate and Transfer (BOT) scheme. Although the project had its setbacks, the eventual result in terms of infrastructural rehabilitation was a success.

Public Private Partnerships (PPPs) in Nigeria are entered into with foreign companies as well, and this serves as a source of foreign investment. A terminal building at the Nnamdi Azikiwe Airport Abuja, for example, was constructed by a Chinese firm CCECC and opened for use in late 2018. In September 2017 the federal government disclosed that the Federal Executive Council had approved the concession of Murtala Muhammed International Airport in Lagos as well as the Nnamdi Azikiwe International Airport in Abuja (Agbakwuru 2017). Although the concessionaires were not disclosed, the Minister of State for Aviation had earlier stated that foreign investors were free to take part in the planned concession of the international airports (Nnodim, 2016). Similarly, the government of Osun State in Nigeria signed a concession agreement for completion of an airport with a company in partnership with a Turkish company (Vanguard News 2017). While FDI has the potential to finance infrastructural development, the eventual impact of FDI on the long term in developing countries has been a subject of debate because investors may be mainly driven primarily by the need to maximize 
profits. This raises concern about the kind of economic growth brought about by FDI and whether it is sustainable in the long term (UNCTAD 2004, p.9).

\section{Employment and Education in Nigerian Aviation}

Creation of employment opportunities within the aviation industry is a major way of achieving economic development. FDI is seen as an avenue for job creation, indirectly leading to poverty reduction in host communities because foreign firms operating within the aviation industry, whether in connection with infrastructural development or airline business, will ordinarily employ labour from Nigeria residents. Some portion of the more than 650,800 jobs (Adekola 2017) in the aviation sector are encompassed by foreign firms. But the development of labour capacity, not mere unskilled and short-term employment, is then at issue.

Human development is vital to economic sustainability and can be achieved through capacity building and skill acquisition. Ensuring inclusive and quality education for all and promoting lifelong learning in the aviation industry requires the provision of aviation education and skills training in Nigeria. The establishment of aviation learning institutes and other related institutes will ensure that more people in Nigeria receive education and acquire skills to be used in the industry. Technical education on aviation is given more attention in Nigeria than other aspects of aviation, as the available aviation institutions focus mostly on aviation technology. Using the International Aviation College in Ilorin as an example, the curricula of the school include pilot courses, technician courses, flight dispatcher courses and so on. The same is true for the Nigerian College of Aviation Technology in Zaria. Some other aviation institutions offer courses in management, business planning, marketing, strategic planning, but it is notable that aviation education in the area of law is lacking in Nigeria. There is currently no university in Nigeria teaching Aviation Law as a course at undergraduate level; it is only available in very few universities at postgraduate level. Meanwhile, Aviation Law is a core aspect of aviation as it regulates the industry itself.

\section{Infrastructure and Innovation}

SDG 9 promotes the building of resilient infrastructure, based on inclusive and sustainable industrialization and on innovation. Achieving this in the aviation industry requires "quality, reliable, sustainable and resilient aviation infrastructure and increase [to] its efficiency" (ICAO 2016). Aviation infrastructure, chiefly air navigation systems and airport facilities, is vital to aviation safety and enhances air transport operations. Air 
navigation services include air traffic management services, control, air navigation, search and rescue services, charts and distribution, aeronautical meteorological services among others. Airport facilities are those utilised by air passengers as well as other users of the airport, including terminals, parking facilities, clinic services, lounging areas, ground handling facilities, banking facilities, registered taxi services, escalators, cooling system and so on.

Having the necessary aviation infrastructure in good condition is instrumental in the prevention of accidents especially those caused by meteorological factors. Bad weather is a contributory cause of air accidents and it has contributed to air accidents in Nigeria in the past. The goal of sustainability in infrastructure and innovation must be achieved by "enhancing scientific research, technological capabilities, research and innovation" (ICAO 2016). This entails funding aviation related research activities in institutions of learning as well as building up scientific and technology capabilities in the aviation sector. Scholarship awards and scholarly competition among students can contribute. An inclusive and sustainable industrialization will ensure that domestic skills in the aviation industry are improved and consideration is given to local firms in the industry during projects. Developing countries in particular are thus enjoined to make aviation development a fundamental part of their economic development plans.

\section{Climate Change}

Aviation is considered "a small but important contributor to climate change [as it] accounts for about $2 \%$ of total global CO2 emissions and about $12 \%$ of the CO2 emissions from all transportation sources" (ICAO 2010). Aviation environmental issues include aircraft and airport noise, aircraft engine emissions, waste management, and air pollution. At the international level, aviation environmental issues are considered as industry-specific issues and are as such addressed within the framework of $\mathrm{ICAO}^{1}$, which has consequently adopted International Standards and Recommended Practices (SARPs) on Environmental protection. ${ }^{2}$ The SARPS do not have the force of law, and are rather standards governing international aviation safety that member states are obliged to implement through their domestic laws (Dempsey, 2004). These standards are aimed at reducing or limiting the

\footnotetext{
${ }^{1}$ See Article 2(2) of the Kyoto Protocol to the UNFCC.

2 This deals with the protection of the environment from the effect of Aircraft Noise and on Aircraft Engine Emissions and are designated as Annex 16 to the Chicago Convention.
} 
environmental impact of $\mathrm{CO} 2$ emissions from international aviation and are provided to member states as guidance and for use in their various jurisdictions.

\section{Domestic Regime}

Any discourse on FDI in Nigeria must necessarily involve two key laws governing foreign investment in Nigeria. These are the Nigerian Investment Promotion Commission Act 1995 (NIPC Act) and Foreign Exchange (Monitoring and Miscellaneous Provisions) Act. Both laws were enacted to attract and promote foreign investment, and it is observed that they do not contain any sustainable development provisions in relation to the industry considered here.

The legal and policy framework of FDI in Nigeria involves laws and policies applying to all sectors of the Nigerian economy, as well as industry specific laws and policies. FDI in the aviation industry in this regard is regulated by those laws applicable to all sectors as well as aviation specific laws and here we consider only the laws and regulations that relate to the aviation industry.

The Civil Aviation Act 2006 is a foremost aviation law containing sustainable development provisions in terms of economic development is. It is the primary legislation governing civil aviation in Nigeria and promotes economic development by encouraging local content. It thus affects how foreign or multinational firms enter a market (Qiu \& Zhigang, 2001, p. 101). One restriction the Act places on foreign investment in the aviation industry relates to air transport operations through prohibiting non-Nigerians and companies or corporations not registered in Nigeria from being granted a licence for an aerodrome (Civil Aviation Act s39). This gives indigenes and indigenous companies an opportunity to explore business opportunities in this area without fear of competition of foreign firm and can be an avenue for youth employment that leads to the reduction of poverty in the country.

Although foreign investors can indeed invest in airline business in Nigeria, the Act limits the amount that can be invested by them in an airline company. Only Nigerians or a company registered in Nigeria and controlled by Nigerians can be given a licence to operate commercial air transport in Nigeria (Civil Aviation Act s.33(2)). The Act in this regard "overrides" the NIPC Act which gives non-Nigerians the right to invest and participate in the operation of any enterprise in Nigeria. The Civil Aviation Act uses the language of "notwithstanding" the provisions of the NIPC Act. The Nigerian 
Civil Aviation Regulations 2015 (Nig. CARs) 3 made pursuant to section 30 of the Act further provide that for an airline company seeking to be registered in Nigeria and be eligible for an Air Transport Licence must show a majority of the shares of the applicant airline company to be held by Nigerians (Nig. CARs pt. IS18.2.2.2(A)(2)(ii)(b)). Foreign investment in the airline business is regulated by this provision to guarantee indigenous ownership of airlines even with the inclusion of foreign investment in the airline company.

The foreign restriction regime over airline ownership fosters the development of indigenous airlines in the industry as there is no competition with foreign airline companies which might otherwise force them out of the market. There is no doubt that many indigenous airlines cannot stand the competition with stronger airlines from foreign countries. In fact, the lack of adequate operational capacity has been a problem associated with airlines in Nigeria particularly as it relates to finance. There have been instances were some airlines were taken over by the Asset Management Corporation of Nigeria $(\mathrm{AMCON})$ due to the inability of the airlines to repay loans taken by them.

The Insurance Act of 2003 also promotes local content and contains provisions on economic development and sustainability. The Act regulates all insurance businesses and insurers in Nigeria and insurance or reinsurance business in respect of any life, asset, interest or other properties in Nigeria businesses which are classified as domestic insurance can be transacted only with companies registered under the Act (Insurance Act s72 (1)). Domestic insurance or reinsurance businesses include liability insurance as well as accident insurance (Insurance Act s72 (2)). Insurance is a vital aspect of aviation business and aviation insurance involves coverage for the operation of aircraft and the risks involved in aviation. It generally covers physical damage to the aircraft as well as the legal liabilities of the air carrier (Havel, 2014). The liability of the air carrier during air operations goes beyond passengers, extending to third parties on the ground (Civil Aviation Act s.49(2)). Airlines as well as other service providers in the aviation industry are mandated to carry insurance, the absence of which is a sufficient reason for refusal, suspension or revocation of the permission to operate the air transport service in Nigeria (Civil Aviation Act s.74). Foreign companies in the aviation industry are therefore also mandated to utilise the services of insurers in Nigeria.

Mandating transaction with indigenous insurance firms is a way foreign investment is made to promote economic development in the country. The

${ }^{3}$ Nigeria Civil Aviation Regulations, Federal Republic of Nigeria Official Gazette No. 175 Vol. 102 of 14 December 2015 (Government Notice No. 128). 
local content considerations in the Insurance Act promote economic development in the insurance sector by increasing the capacity of domestic firms to produce for the domestic market. Insurance with foreign companies can only be permitted in exceptional cases, that is, where the commission is satisfied that the exceptional nature of the risk cannot be placed with an insurer in Nigeria. In such a case, the commission may in writing permit insurance outside Nigeria (Insurance Act s 72 (4)).

Further, aviation businesses are specifically required to be insured with Nigerian insurance companies. The National Insurance Commission (NAICOM) issued a circular in 2014 containing requirements for aviation insurance placement and returns. As a general requirement, "the establishment of underwriting terms and conditions for any Aviation and its associated risks in Nigeria shall be the responsibility of an insurer duly licensed to transact insurance business in Nigeria" (NAICOM 2014).

A further law that promotes economic development is the Infrastructure Concession Regulatory Commission Act 2005 (ICRC Act) which governs public private partnership (PPP) arrangements. As noted above, PPP arrangements are becoming popular in the aviation industry particularly in respect of infrastructure and foreign companies have been actively involved in PPPs in the industry. The ICRC Act encourages foreign firms involved in PPP arrangements to team up with the smaller and medium sized local contractors in performing their duties under the contract. This gives indigenous contractors an opportunity to get involved in projects which they ordinarily would not be able to perform on their own based on lack of capacity.

\section{Capacity Building and Human Development}

The regulation of FDI concerning capacity building mostly relates to technology transfer. A law providing for this is the National Office for Technology Acquisition and Promotion Act (NOTAP Act) which applies to all sectors including aviation as it provides for the transfer of foreign technology to Nigeria. It established the National Office for Technology Acquisition and Promotion (NOTAP) for monitoring purposes. Technology transfer agreements contain clauses which guarantee employment, exposure and training of the appropriate Nigerian staff, supported by an economic evaluation of the agreement based on those qualities (NOTAP Guidelines 2018 sections $2 \& 4.3$ ). The NOTAP also assists Nigerian parties to ensure that they acquire the best contractual terms and obligations when entering into any contract on technology transfer with foreign companies. Transfer of 
technology to indigenous entities through FDI is a means of human development as well as capacity building.

Further, the National Civil Aviation Policy 2013 (NCAP) stresses the need for human resources development as it identifies a shortage of skilled personnel in the industry. It notes that there is limited aviation training capacity within Nigeria and that the available training institutions are few and "have not always kept pace with the advancements in civil aviation and training technology" (NCAP 2013, Part 4). Importantly, it also notes that non-scheduled flights are undertaken by foreign registered aircraft in Nigeria and are operated by foreign pilots. The NCAP therefore provides that the government should provide the necessary incentives to facilitate private sector investment in the establishment of Aviation Training Organisations (ATOs); support the maintenance of a database by the Nigerian Civil Aviation Authority (NCAA) on aviation training needs and capacities in Nigeria; and publish periodic reports on the state of aviation training in Nigeria. It was expected that these requirements would bring about an adequate number of highly trained and skilled personnel in charge of aviation in Nigeria (Part 4 NCAP 2013).

The Civil Aviation Act 2006 addresses the environmental effects of aircraft operation (Civil Aviation Act sections 40, 41) by making it mandatory for the NCAA in licensing aerodromes to have regard to the need to minimize so far as practicable any adverse effect the presence of such aerodrome(s) may have on the environment. Similarly, the Nigeria Civil aviation Regulations prescribes environmental standards for aircrafts registered and operating in Nigeria. These SARPs on environmental protection adopted by ICAO are implemented by the NCAA through the Civil Aviation Regulations and air operators cannot operate an aircraft in commercial air transportation in Nigeria contrary to the requirements of the applicable standards (Part 10.1.1.4.Nig. CARs). The regulations prescribe maximum noise levels, fuel venting standards.

\section{Conclusion}

FDI and foreign investment generally remain important to the aviation industry and from all indications the government of Nigeria will continue to intensify efforts to attract foreign investments into the industry believing this to be required for the development of the sector. Public Private Partnerships are becoming a trend for infrastructural development in the industry and are notably evident in airport concessions. This arrangement paves way for foreign companies to invest in the aviation sector in the country. The SAATM, a new development in the African air transport sector, is another 
imminent channel of FDI inflow into the Nigerian aviation industry. There are, as shown, other current legal and policy frameworks in the aviation industry which regulate FDI to make provision for sustainable development. Such are the laws and regulations promoting local content and those promoting environmental sustainability. Nonetheless, it is observed that these laws and regulations do not emphasize infrastructural development in a systematic way. It is not possible to conclude that sufficient attention has yet been given to aviation infrastructure, whether in its technological or its human dimensions.

\section{References}

Adediran, A. O. (2018). Liability Of Airlines For Cancellation Of Flights In Nigeria, Nigerian Journal Of Contemporary Law, 19 (1), 92

Adediran, A.O. (2017). Will a National Carrier threaten Competition in Domestic Airline Operations in Nigeria: An Examination of the Legal Regime. Issues in Aviation Law and Policy, 16 (2), 288.

Adekola, Shola. (2017). Air transport contributes \$8.2bn to Nigeria's GDP IATA, Nigerian Tribune, Aug 17 www.tribuneonline.ng.com/airtransport-contributes-8.2bn-nigerias-gdp-iata/.

Agabi, Chris. (2017). N20bn for aviation in 2017 budget too low- Sirika. Vanguard Newspaper. 2 Feb, https://www.dailytrust.com.ng/news business/n20bn-for-aviation-in-2017-budget-too-lowsirika/183506.html.

Agbakwuru Johnbosco. (2017). FG approves concession of Lagos, Abuja Airports, $\quad$ Vanguard News. $\quad$ Sep 11. www.vanguardngr.com/2017/09/fg-approves-concession-lagosabuja-airports/

Agreement Between the Government of the People's Republic of China and the Government of the Federal Republic of Nigeria for the Reciprocal Promotion and Protection of Investments 2001.

Air Navigation Act of 1920 (as amended).

Convention on International Civil Aviation (Chicago Convention). (July 2011). Annex 16, paragraph 1.3.

Asset Management Corporation of Nigeria. Act no. 4, 2010.

Capobianco H.M.P. and Fernandes E. (2004). Capital structure in the world airline industry. Transportation Research. Part A, 421-434.

Circular. (2014). NAICOM /CFIO /AVN /RTRNS /CIR /2014/02 dated December 312014

Civil Aviation Accident (CAA) Report NO. FMA/AIPB/383 published on 16th March 2008. 
Civil Aviation Act 2006

Convention on Civil Aviation 1944

Convention Relating to the Regulation of Aerial Navigation signed in Paris in 1919

Dempsey Paul Stephen. (2004). Compliance \& Enforcement in International Law: Achieving Global Uniformity in Aviation Safety. North Carolina Journal of International Law and Commercial Regulation. $30,1$.

Draft Regulations on Competition in Air Transport Services within Africa

Federal Aviation Act of 1958, Pub. L. No. 85-726, 72 Stat. 731 (codified at 49 U.S.C. $\S \S 1301-1557$ (1988)).

FG pledges to attract direct investment to aviation sector, (March 29 2018)

Vanguard News. https://www.vanguardngr.com/2018/03/fg-pledgesattract-direct-investment-aviation-sector/

Foreign Exchange (Monitoring and Miscellaneous Provisions) Act

Gallagher Kevin P., Zarsky Lyuba, (2007) The Enclave Economy: Foreign Investment and Sustainable Development in Mexico's Silicon Valley, Cambridge: MIT Press. 5

Giffen, Thomas Van. Recent Trends in FDI and the Sustainable Development Challenge. CESifo Forum 2/2015 (June)

Havel Brian F., and Sanchez Gabriel S. (2014). The Principles and Practice of International Aviation Law. Cambridge: Cambridge University Press.

Infrastructure Concession Regulatory Commission. (2013). National Policy on Public Private Partnership. (December).

Infrastructure Concession Regulatory Commission (Establishment etc) Act 2005

Insurance Act of 2003 Cap I17 LFN 2004

International Aviation College, Ilorin. http://aviation.africhoice.website/

International Civil Aviation Organization. (2010). Environmental Report 2010, 38 .

International Civil Aviation Organization. (2004). Manual on the Regulation of International Air Transport. 2nd ed., part 4. (ICAO Doc. 9626)

International Civil Aviation Organization. ICAO and the United Nations Sustainable Development Goals, 39th Session of the ICAO General Assembly 27 September - 7 October 2016, www.icao.int/abouticao/aviation-development/pages/sdg.aspx

Investment Promotion and Protection agreement between The Government of the Kingdom of Morocco and the Government of the Federal Republic of Nigeria signed $3^{\text {rd }}$ December 2016, (IPPA). 
Kardos, Michaela. (2014). The relevance of Foreign Direct Investment for sustainable development: Empirical evidence from European Union. Procedia Economics and Finance, 15, 1349 - 1354.

Kaur, Jasmeet. (2013-2014). FDI and Sustainable development: Lessons to Draw for India, Annual Research Journal of SCMS, Pune Vol. 1, 57

Kyoto Protocol to the United Framework Convention on Climate Change (UNFCC) 1997

National Civil Aviation Policy of Nigeria 2013

National Office for Technology Acquisition and Promotion (NOTAP) Act Cap N62 LFN 2004

Nigeria Civil Aviation Regulations, Federal Republic of Nigeria Official Gazette No. 175 Vol. 102 of 14 December 2015 (Government Notice No. 128).

Nnodim, Okechukwu. (2016, 24 May). Govt opens up airport concession to foreign investors. Punch Newspaper. http://www.punchng.com/govtopens-airport-concession-foreign-investors/

Organisation for Economic Cooperation and Development. (2008) Benchmark Definition of Foreign Direct Investment. (4th ed.)

Promoting the development of Indigenous Technology in Nigeria as AU observes African Day for Technology and IP. www.notap.gov.ng/ conent/promoting-development-indigenous-technology-nigeria-auobserves-africanday-technology-and-i?page $=24$

Qiang C., Echandi R. , and Krajcovicova J. (2015). Foreign direct investment and development: Insights from literature and ideas for research. World Bank blog. http://blogs.worldbank.org/psd/foreign-directinvestment-and-development-insights-literature-and-ideas-research

Qiu Larry D. \& Zhigang Tao. (2001). Export, foreign direct investment, and local content requirement. Journal of Development Economics, (66) (1), $101-125$.

Revised Guidelines for Registration and Monitoring of Technology Transfer Agreements in Nigeria 2018. (NOTAP Guidelines)

Sahara Reporters. (2017 February 9). Finally, AMCON Takes Over Distressed Arik Air, Appoints New Management - Arik Owes \#135B Sahara Reporters. www.saharareporters.com/2017/02/09/finallyamcon-takes-over-distressed-arik-air-appoints-new-managementarik-owes-n135b

Schlumberger Charles E. and Vijayakumar Shruti. (2015). Public-Private Partnerships in Airports: Imperatives for Governments. Annals of Air and Space Law, XL, 493. 
Solemn Commitment By African Union Member States To The Implementation Of The Yamoussoukro Decision Towards The Establishment Of A Single African Air Transport Market BY 2017, Assembly/AU/Commitment(XXIV) at the $24^{\text {th }}$ Session of the Assembly of the African Union 30 - 31 January 2015

Sornarajah M. (2010) The International Law on Foreign Investment. $3^{\text {rd }}$ ed. Cambridge: Cambridge University Press.

Stephens Mobolaji S., Ikeogu Vivian, Stephens Omatshola B., and Ukpere Wilfred I. (2014). Empirical Analysis of the Contribution of the Aviation Industry to the Nigerian Economy. Mediterranean Journal of Social Sciences, 5(3), 119.

Strange Tracey, and Bayley Anne. (2008). OECD Insights Sustainable Development: Linking Economy, Society, Environment. Paris: OECD Publishing.

Susic I., Stojanovic-Trivanovic M., and Susic M. (2017). Foreign direct investments and their impact on the economic development of Bosnia and Herzegovina. IOP Conf. Series: Materials Science and Engineering 200, 012019, 3.

Taiwo JN, Achugamonu BU, Okoye O., and Agwu, M.E. (2017). Foreign Direct Investment: Catalyst for Sustainable Economic Development in Nigeria. Saudi J. Bus. Manag. Stud., 2(2) $70-8$.

The Single African Air Transport Market - An Agenda 2063. Flagship Project - Brochure 2-3

Vanguard News. (2017). Osun concessions MKO Int'l Airport to Turkish firm, Vanguard News. Oct 26 www.vanguardngr.com/2017/10/osunconcessions-mko-intl-airport-to-turkish-firm/.

UN General Assembly Resolution 66/288 of 27 July 2012 Annex I

United Nations Conference for Trade and Development. Making FDI Work for Sustainable Development. New York and Geneva 2004. UNCTAD/DITC/TED/9.

United Nations Conference for Trade and Development. Investment Policy Framework for Trade and Development 2015.

United Nations Conference on Environment \& Development Rio de Janeiro, Brazil, 3 to 14 June 1992 AGENDA 21.

United Nations Conference on Sustainable Development. 2012. Rio de Janeiro ( 20-22 June). UN doc. A/CONF.216/16. 